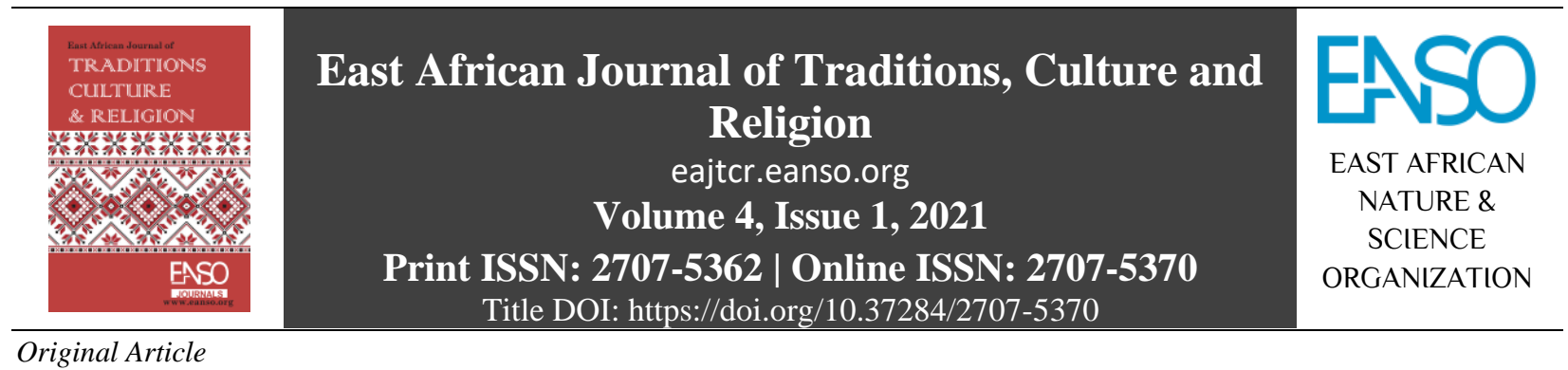

\title{
Why Acholi Traditional War Rituals Cannot Reintegrate Female Lord's Resistance Army Combatants: A Case Study of Kwero Merok War Ritual.
}

\author{
Wotsuna Khamalwa ${ }^{1 *}$ \& Emeline Ndossi ${ }^{2}$ \\ ${ }^{1}$ Makerere University and Kampala International University, P.O. Box 7062, Kampala, Uganda. \\ ${ }^{2}$ Senior Lecturer at the Lutheran Theological College, Makumira in Tanzania. \\ *Author for Correspondence Email: khamalwawotsuna@gmail.com
}

Article DOI: https://doi.org/10.37284/eajtcr.4.1.564

\section{Date Published: ABSTRACT}

08 November 2021 The Acholi are Nilotic Negroes who are part of the Lwo speaking people who migrated from Bahr-el Ghazal in the Sudan about 1600 AD. A section

Keywords: of the Acholi community under the umbrella of Lord's Resistance Army (LRA) waged a civil war against the sitting government of Uganda in 1986.

Acholi, LRA rebels abducted numerous children from Acholi-land and the neighbouring Lango community in northern Uganda regardless of their gender. The female returnees, whether they were recruited willingly or otherwise, are believed to have committed atrocities towards their own Acholi people during the period of insurgency. During their re-integration, these women were culturally challenged, not only for the atrocities they were believed to have committed while in the bush, but because of their status as women who violated their gender role status. The Acholi traditional culture does not approve of female combatants and some of the society members hold strong reservations regarding the new status of these women! They argue that the status of these former combatants who took lives of their own kin and kith is incongruent with Acholi perception of women as life givers, carer-givers and protectors! The article cautions that the stigma that the female returnees experience even after going through the different rituals is an indication that they are not fully reintegrated! Acholi traditional culture was in this case selected because it has been a pioneer through its traditional rituals to reintegrate these women in the Northern Ugandan community. However, it was noted in this article that cultural rituals such as kwero merok cannot fully reintegrate LRA female combatants.

\section{APA CITATION}

Khamalwa, W., \& Ndossi, E. (2021). Why Acholi Traditional War Rituals Cannot Reintegrate Female Lord's Resistance Army Combatants: A Case Study of Kwero Merok War Ritual. East African Journal of Traditions, Culture and Religion, 4(1), 69-79. https://doi.org/10.37284/eajtcr.4.1.564

69 | This work is licensed under a Creative Commons Attribution 4.0 International License. 


\section{CHICAGO CITATION}

Khamalwa, Wotsuna \& Emeline Shilunga. 2021. "Why Acholi Traditional War Rituals Cannot Reintegrate Female Lord's Resistance Army Combatants: A Case Study of Kwero Merok War Ritual”. East African Journal of Traditions, Culture and Religion 4 (1), 69-79. https://doi.org/10.37284/eajtcr.4.1.564.

\section{HARVARD CITATION}

Khamalwa, W., \& Ndossi, E. (2021) "Why Acholi Traditional War Rituals Cannot Reintegrate Female Lord's Resistance Army Combatants: A Case Study of Kwero Merok War Ritual”, East African Journal of Traditions, Culture and Religion, 4(1), pp. 69-79. doi: 10.37284/eajtcr.4.1.564.

\section{IEEE CITATION}

W. Khamalwa, \& E. Ndossi. "Why Acholi Traditional War Rituals Cannot Reintegrate Female Lord's Resistance Army Combatants: A Case Study of Kwero Merok War Ritual”, EAJTCR, vol. 4, no. 1, pp. 69-79, Nov. 2021.

\section{MLA CITATION}

Khamalwa, Wotsuna \& Emeline Ndossi. "Why Acholi Traditional War Rituals Cannot Reintegrate Female Lord's Resistance Army Combatants: A Case Study of Kwero Merok War Ritual”. East African Journal of Traditions, Culture and Religion, Vol. 4, no. 1, Nov. 2021, pp. 69-79, doi:10.37284/eajtcr.4.1.564.

\section{INTRODUCTION}

The Acholi are Nilotic Negroes who are part of the Lwo speaking people who migrated from Bahr-el Ghazal in the Sudan about 1600 AD. ${ }^{1}$ A section of the Acholi community under the umbrella of Lord's Resistance Army (LRA) waged a civil war against the sitting government of Uganda in $1986 .^{2}$ LRA rebels abducted numerous children from Acholiland and the neighbouring Lango community in northern Uganda. These children from Gulu, Kitgum, Pader, Apac, and Lira were often recruited into combat regardless of their gender. The female returnees, whether they were recruited willingly or otherwise, are believed to have committed atrocities towards their own Acholi people during the period of insurgency.

During their re-integration, these women were culturally challenged, not only for the atrocities they were believed to have committed while in the bush, but because of their status as women who violated their gender role status. The Acholi traditional culture does not approve of female combatants and some of the society members hold strong reservations regarding the new status of these women! They argue that the status of these former

\footnotetext{
${ }^{1}$ R. M. Bere, An Outline of Acholi History, Uganda Journal 11, (1947), 1

2 Heike Behrend, and Ute Luig (eds.). Spirit Possession: Modernity in Africa. Oxford: James Currey, (1999), 116.

${ }^{3}$ Susan McKay and Dyan Mazurana. 'Where Are the Girls? Girls Fighting Forces in Northern Uganda, Sierra Leone and Mozambique: Their Lives during and after War'. Montreal, Quebec: Rights \& Democracy, (2004), 73.
}

combatants who took lives of their own kin and kith is incongruent with Acholi perception of women as life givers, carer-givers and protectors!

McKay and Mazurana report that close to $49 \%$ of the women in LRA captivity were soldiers and seventy-two per cent received both weapons and military training; with $8 \%$ in advanced military training. ${ }^{3}$ One of the female returnees testified to this saying, "As a woman you have to fight when attacked by Uganda People's Defence Forces (UPDF). You run with your baby on the back, and you also ensure protection for your child". The testimony confirms F. K. Girling's observation that in Acholi traditional culture, child-care was a woman's role. ${ }^{4}$ Helen Nambalirwa Nkabala ${ }^{5}$ explains that since child-care was a woman's role, while in the bush, besides fighting women were also assigned this role. The women's roles as combatants overlapped the men's in LRA, as some were spies who relayed information about their adversary. ${ }^{6}$ When they returned from the bush the customs and traditions subjected them to the cleansing rituals, including kwero merok that were originally meant for male warriors.

\footnotetext{
${ }^{4}$ F. K. Girling, The Acholi of Uganda. London: Her majesty's Stationery Office, (1960), 7.

${ }^{5}$ Nambalirwa, Helen Nkabala. "There is no Difference Between Moses and Kony" A Critical Analysis of the Contextual Use of Some Old Testament Texts and Motifs in Early Years of the Lord's Resistance Army. (A Doctoral Dissertation, School of Mission and Theology, Stavanger, 2010).

${ }^{6}$ See McKay et al, 2008, p. 175.
} 
The researchers observed that the community members still stigmatize these women as being militant and rebels despite the fulfilment of the rituals. The study established several cultural reasons for such an attitude. Stigma in this project refers to the shame and disgrace felt by the female LRA returnees, coupled with the trauma that follows the low value and discrimination which society associated with female returnees as rebel combatants. In one of the interactions with female returnees, one victim stated that when she came back, life was not that easy because of stigmatization. ${ }^{7}$ She asserted that despite the efforts of several institutions to avert abuses encountered by them, stigmatization remained a reality that was hard to fight. It was upon the victims to give up and cease to care as time went by. ${ }^{8}$ Another victim pointed out that full reintegration was a myth to them, especially because men found it hard to marry them. The society often scorned the men who wished to marry them, which ridiculed their personality and identity as female returnees. ${ }^{9}$ Elise F. Barth, elaborating on the experiences of marriage crisis former fighters face in Africa says that the gap is rather big between men and women on the possibility of getting marital partners after coming from war. Barth reports that only $3.2 \%$ of the women fighters were married to civilians, compared to $96.4 \%$ of men. ${ }^{10}$ These figures illustrate some of the cultural biases that some people have towards female combatants.

Furthermore, one of the religious leaders attests to the LRA women's views and testimonies, observing that, "The greatest challenge is that some people don't co-operate with them. They feel rejected." 11 Another informant remarked that "Some

\footnotetext{
${ }^{7}$ Interview with a female ex-child soldier on 14 February 2008 at Tailoring School in Gulu.

8 Ibid.

${ }^{9}$ Ibid.

${ }^{10}$ Elise F. Barth, 'Peace as Disappointment: The reintegration of female soldiers in post-conflict societies- a comparative study from Africa' (Oslo: A report for the Norwegian Ministry of Foreign Affairs, 2002), 31.

11 Interview with a religious leader on 8 February 2008 in Acholi Religious Leaders' Peace Initiative (ARLPI)- Office, Gulu.

12 Interview with a religious leader on 10 February 2008 in Parish office-Gulu- District.
}

communities have not been good to these people, they have been pointing fingers at them as a way of saying, "you were not around with us, you were somewhere and you did something wrong." 12 In addition to oral sources, Erin Baines in the article "Roco Wat I Acoli: Restoring Relationship in Acholi-land: Traditional Approaches to Justice and Reintegration" is of the view that "Half of the informants identified name labelling as their biggest challenge upon return..."13 The question is why the name-calling should be there if LRA returnees have undergone traditional rituals! Joanne Corbin also points at harassment of LRA returnees by community members as a major challenge of reintegration. ${ }^{14}$ Susan McKay and Dyan Mazurana argue that in the African Great Lakes region they found that girls face greater stigmatization upon reintegration than boys and that child mothers need more support because this cohort faces higher levels of community rejection. ${ }^{15}$ A lawyer, working with the female returnees in Acholi reiterates the above view. She notes that "The fact that some of the exchild soldiers are women makes them more vulnerable during reintegration" 16 This view is also supported by Sverkar Finnstrom when he says that "Ex-rebel girls more than ex-rebel boys are stigmatized by society, even if mutedly." ${ }^{17}$ From the above sources it is evident that stigma is a reality among the female combatant returnees in the Acholi community. The baseline of the stigma is rooted in the violation of traditional cultural norms. The concept of female warriors is alien to the Acholi tradition, and kwero merok was not meant for women but men who fought enemies and not their own people.

13 Erin Baines. 'Rocowat I acoli: restoring relationship in Acholi-land: Traditional approaches to justice and reintegration' (Vancouver, Canada: Liu Institut Global Issues, 2005), 35 .

14 Joanne Corbin. Returning Home: Resettlement of formerly Abducted Children in Northern Uganda. Disasters 32, (2): (2008), 329.

${ }^{15}$ McKay et al, (2004), 37.

${ }^{16}$ Interview with a lawyer on 14 February 2008 in Transa Rock Hotel, Gulu.

17 Sverker Finnstrom, Living with Bad Surroundings: War, History and Everyday Moments in Northern Uganda. Durham and London: Duke University Press, 2008. (Finnstrom, (2008), 193.

71 This work is licensed under a Creative Commons Attribution 4.0 International License. 
The stigma women undergo due to the cultural reasons contradicts the meaning of reintegration given by the international community in the Paris Principles document which states, inter alia, that reintegration ought to fully enable these women to get their basic needs as well as providing them with meaningful roles and identities that give them opportunities to live as people who have been accepted by their families and communities, and be allowed to live a dignified life and access their basic rights. Consequently, the following section explores further the features of the traditional Acholi culture and its implication on kwero merok ritual.

\section{The Role of Culture in the Reintegration of Female Returnee Combatants}

According to Geert Hofstede, culture is a collective programming of the mind that distinguishes the members of one group or category of people from another. ${ }^{18}$ Consequently, culture is learned in the social environment of specific group, or category of people, and shared by people living within that context. $^{19}$ It is consciously or unconsciously acquired through social interaction with other people in the community as noted by Hofstede. Because of culture, people learn to hear, see and do certain things in a certain way. Later it turns out to be their natural behaviour, distinct from other societies. Acholi traditional culture has great consequences towards the reintegration process of LRA female returnees. ${ }^{20}$

In cultures like that of the Acholi where people have been brought up with the concept that fighting is a man's role, it is unusual to see female combatants. The article makes use of masculinity dimension which diversifies gender roles. ${ }^{21}$ In high avoidance cultures, people are conservative and restorative towards the unknown since what is different is unsafe and dangerous. ${ }^{22}$ The author further observed that the experience of war returnees in individualistic cultures where family network is limited to nuclear family is different from those of

\footnotetext{
${ }^{18}$ Geert Hofstede et al. Cultures and Organizations: Software of the Mind. New York: Mc Graw-Hill Press, (2010), 9.

${ }^{19}$ Ibid.

20 Thomas Harlacher et al. Traditional Ways of Coping in Acholi. Kampala: Intersoft Business Service Ltd, (2006).

${ }^{21}$ Hofstede et al, 297.
}

collective cultures with an extended family network..$^{23}$ It is clear that the collective norms within Acholi culture affected these women during their reintegration. So, the following section looks at the notion of fighting and killing from traditional Acholi perspective.

\section{The Traditional Rituals for Reintegrating Female Returnees}

The Acholi traditional belief systems asserts that there are diseases and calamities caused by the natural and supernatural powers. The spirit related diseases are believed to be caused by the ancestors, chiefdom joggi or free joggi. The ancestors and chiefdom joggi are said to cause mild diseases with the intention of disciplining those who had misbehaved while the free joggi have the motive to harm even out of sheer malice. There are also traditional healers for the natural and supernatural diseases such as the ajwaki and herbalists. ${ }^{24}$ The tradition mandates the Acholi elders to mediate between the dead and the living. ${ }^{25}$ Elders were also consulted in case there was a conflict in the clan. In case of certain calamities or diseases beyond their ability, then ajakwa was called. Ajakwa was typically a diviner woman with spiritual power which enabled her to heal.

The Acholi believe that a person who has killed or has been in the battle field or passed close to the dead body must undergo special rituals to cleanse them from possible possession of cen. Killing according to the Acholi, brings bad omen to the killer, the immediate family, the clan and can be passed on to the next generation. The disaster can be in form of diseases or mysterious ailments, misfortunes or even death. ${ }^{26}$ The vivid signs of possession by cen include the desire to do bad deeds, the heart to harm, bad dreams now and then, shouting, the shaking of the body, madness etc. Killers who have not been cleansed are believed to be filled with the Ojebu spirit that nurtures bad luck that often leads to misfortunes among them and

\footnotetext{
22 Ibid, 203.

23 Ibid, 202.

${ }^{24}$ Harlacher et al, 56.

${ }^{25}$ Ibid, 57.

${ }^{26}$ Ibid, 59.
} 
among clan members. Consequently, warriors are feared for the possibility of possessing cen which might incite them to kill again, ${ }^{27}$ that is why rituals such as kwero merok were perfumed on soldiers after battle.

In accordance with the belief, in case a person is possessed by cen it does not stay in the person all the time, but it comes at will; for its time of surfacing is unpredictable. It is for this reason that the female combatants like their male counterparts were subjected to kwero merok as a cleansing ritual, in the presence of their extended family members since Acholi are more of a collective cultural society.

It should be pointed out here that the Acholi belief system was built over time based on social values; and since women warriors were unheard of in the society, there was no provision of rituals for them. The appearance of female warriors is new to the Acholi traditional culture and has thrown the tradition off-balance, forcing them to try to reintegrate these people using rituals that were originally meant for men. It is this notion that still stigmatises the female returnees, because society only accepts them verbally but deep down there remains suspicion and apprehension. The role and procedure of kwero merok are elaborated below.

\section{Acholi Ritual for Soldiers Who Have Killed in war}

As mentioned earlier, in the Acholi traditional culture, unique rituals are performed in order to cleanse soldiers who have killed the enemy during war, to keep relatives and the clan safe from diseases, death and misfortunes. These rituals are believed to appease the spirits of the dead, and kwero merok ritual is one of them. ${ }^{28}$

This discussion centres on the rituals which were used to reintegrate the female returnees from LRA and yet traditionally were meant for male warriors who had returned from battles. ${ }^{29}$ But Baines suggests that they were sometimes also used to cleanse those who had killed people from other antagonistic clans. ${ }^{30}$ In the event of reintegration of

\footnotetext{
${ }^{27}$ Ibid, 63.

${ }^{28}$ Ibid, 59.

${ }^{29}$ Ibid, 100.

${ }^{30}$ Baines, 30.
}

LRA returnees, kwero merok was preceded by other rituals like nyono tonggweno and lwoko pik wang. Nyono tong gweno was meant for welcoming someone who had been away from home for a long time, and was performed at family or clan level. People believed that in essence individuals might have contracted spirits which could bring misfortunes to the whole family. Thus, they needed to be cleansed. It should be mentioned here that rituals like nyono tong gweno could not cleanse people from the aggressive spirits such as cen which needed the consultation of ajwaka (medicine women or men).

Another preceding ritual to kwero merok is lwoko pik wang, which literally means washing away tears of the family members over the person that had left the family and assumed dead and then returned. Some of these women had been mourned by their families as having died because they left the families for very long and were assumed to be dead. Culturally, such tears which were shed for people who later returned were to be washed away through rituals. The Acholi believe that such mourning could cause misfortunes in the family if not cleansed. Kwero merok is strictly performed after the observation of the preceding rituals where necessary and strictly meant to welcome and cleanse soldiers from cen. It is unfortunate that kwero merok was performed at all for the women returnees who had turned against their own people. The tradition embedded in this ritual seemed not to have been upheld when the Acholi elders and chiefs used it with LRA returnees. Hence its traditional core values and purpose of welcoming back male heroes was ignored. The female returnees from LRA were perceived, not as returning heroes but returning villains in a ritual culturally meant for heroic men! This possibly explains the bottom line of stigma that the female returnee combatants still undergo albeit silently, because society perceives them as villains and not heroes!

It should also be put into account that some of the performances and utterances in kwero merok's procedures evoke the sense of guilt among the LRA returnees, and escalate more hatred and stigma by the community towards them. The ritual demands

73 This work is licensed under a Creative Commons Attribution 4.0 International License. 
that several performers including lakwe the lead performer, must have killed an enemy and gone through the same ritual. Lanwoja is often selected because of one's bravery and he is the one who spears the goat in the grazing field. Lawayo and a virgin girl are also very important in the ritual. ${ }^{31}$ The ritual starts vehemently with the merok (enemy) song that mocks and scorns the enemy, while it praises and elevates the male killer for the heroic act. The song also rebukes and curses the spirit of the dead to leave the killer and the community members, especially those who have attended the ceremony. The enemy is mocked with spears and sticks, the killer then blows a horn to announce his triumphant victory, and later the elders plead with the ancestral spirits to help set the warrior killer, and the general community free from cen.

With what mirth can a female returnee combatant blow the horn, which is predominantly a man's object in Acholi? And how can they triumphantly blow the horn when instead of killing the adversary they butchered their own people whose relatives are in the arena with heavy hearts and teary eyes? One wonders what heroic welcome the community can accord to the killers of their dear ones, especially when the killers are part and parcel of the community? The kwero merok becomes verbally symbolic in accepting the returnees but the bottom line is that trauma remains since the society silently points accusing fingers at the female combatants as murderers and traitors, so they cannot fully associate with them. The female returnees cannot fully exonerate themselves from the gruesome acts they committed while in captivity! In spite of the psychotherapy embedded in kwero merok, the reality continues to haunt them in dreams.

\section{The Response of the Acholi People to the Female Combatants}

It is notably observed that the Acholi community has divided opinion towards the female returnee combatants. Some of the community members disrespect and resent their identity as female ex-

\footnotetext{
${ }^{31}$ Harlacher et al, 10.

32 Archbishop John Odama was the chairperson of ARLPI Acholi Religious Leaders' Peace Initiative (ARLPI) during the time of my field research. He is internationally known for his contribution in creating awareness about the nature of the
}

LRA soldiers. The fact that they held guns and actually participated in combat draws scorn and sneers from the community, since women customarily ought to be peacemakers. As Archbishop John Odama ${ }^{32}$ explicitly observed, and we quote, "... this time this is something strange which has happened where women or girls are being forced to fight... This is completely against the culture; the peace maker is made the author of violence. This is one thing which people are very seriously talking about." ${ }^{33}$ Bishop Odama's remarks affirm that the Acholi community is not comfortable with the identity of the combatant female returnees, since it runs against the traditional role of a woman in the society.

In agreement with Bishop Odama, another religious leader states that although Acholi women were aggressive, the war has increased their aggression. ${ }^{34}$ He looks at the position of women combatants as the driving force behind the high degree of hostility among them. The opinions of the different informants mirror the core value of Acholi that is embedded in the fact that women are not supposed to engage in war activities, especially on the battle fields. The LRA rebellion broke this belief system when it paraded women at the frontline with their children strapped on their backs! It is clear that Acholi traditional culture still determines the gender roles in the community, assigning women different roles to play in society from those of men.

Archbishop Odama admires the old stance of a woman in Acholi culture that makes her an emblem of peace and not conflict. She was a conveyor of blessing and not of curses. He notes,

You know, especially the elderly women were the ones giving blessings before going for hunting and before planting. It was she who gave blessings and then it was also a woman who would give blessings especially when people

\footnotetext{
LRA war and its consequences on the people of Northern Uganda.

${ }^{33}$ Interview with Archbishop John Odama on 13 February 2008 at Catholic Cathedral in Gulu town.

${ }^{34}$ Interview with a religious leader on 8 February 2008 in Gulu District.
} 
were going for things like fighting. It would be the woman who gives blessing. ${ }^{35}$

Okot p'Bitek concurs with the sentiments of Archbishop Odama about the quality that made every Acholi woman respected as a mother, when he elaborately states,

When a chief wished to attack another chief, he called his war leaders and heads of the clans together and told them the rightness of the cause for which they were to fight... On the eve of battle the entire army gathered before the chief's enclosure. The chief's mother, holding a leafy twig of (olwedo) tree spoke. She repeated the reasons for the attack about to begin, stressing that her son's warriors would fight for the right cause. $^{36}$

In his report, Peter Singer remarks that the Acholi warriors did not attack children, women or the elderly, nor did they destroy crops, granary stores or livestock. The destruction of the mentioned subjects and objects were viewed as taboo that would soil one's lapir, and risk losing the blessings of the ancestors that was often tantamount to losing the war. Kony, the leader of LRA, initially respected the Acholi core value of exempting women from the war arena. Helen Nkabala Nambaliwa observes that women were not part of LRA in the beginning but there were circumstances that forced the LRA soldiers to recruit females. ${ }^{37}$ According to her, the reasons that inspired the recruitment of females included the fact that the men in abduction would struggle to escape to satisfy their sexual urge in the villages, yet sex was forbidden. Kony became afraid that his vigilant combatants would die of anxiety for sex or contract HIV/AIDS and decided to abduct and recruit women to curb the sexual desire of the male fighters; and help in the domestic chores as men concentrated on the battles. However, he later changed and used women as fighters majorly due to the scarcity of men on the battlefields while there was an increase of pressure by the Uganda People's

\footnotetext{
${ }^{35}$ Interview with Archbishop Odama on 13 February 2008, Catholic Cathedral in Gulu.

${ }^{36}$ Okot p'Bitek, Okot. Religions of the Central Luo. Nairobi: East African Literature Bureau, (1971), 151.

${ }^{37}$ Nkabala, 41

38 (Nkabala, 42-45.
}

Defence Forces (UPDF) against them. ${ }^{38}$ It is evident that initially Kony had respect for Acholi gender roles during war as authors of blessings and non-combatants. Annan substantiates this opinion when he argues that women were principally recruited not to become fighters, but to become 'wives' and mothers." 39

\section{The Implications of Acholi Culture on the LRA Combatants}

Girling reports that traditionally Acholi gender roles were clearly spelt out and each gender had obligations to both the family and society. Men's roles were predominantly farming, herding the domestic animals, hunting, building and fighting, while the women were expected to weed, harvest, cook, do child care, fetch water and fire wood as well as doing other domestic chores. ${ }^{40}$ The men and women were socialized to fulfil their different obligations right from childhood. Geert Hofstede's view argues that masculinity cultures diversify gender roles unlike femininity cultures where the roles overlap. ${ }^{41}$ Consequently, masculinity cultures do not only differentiate, predestine and generalize the roles of men and women, but also shape their behaviour. This explains the variant opinions of the various informants that seem to echo one thing in Acholi traditional culture, namely that women were peace-makers and not war-mongers. The Acholi cultural position of women during war is generalised to be that of authors of blessings who are non-militant.

Consequently, every woman knew her boundary in the event of war and dared not go to the battle field because tradition prohibited it. That is why the roles of the female combatants while in captivity runs counter to traditional Acholi culture. Little wonder then that one informant said he does not support female combatants, because according to him, militarization makes women macho (more aggressive or manly). ${ }^{42} \mathrm{He}$ insinuates that women are supposed to be peaceful and gentle. To him the

\footnotetext{
${ }^{39}$ Annan et al, 9.

${ }^{40}$ Girling, 7.

${ }^{41}$ Hofstede, 297.

${ }^{42}$ Interview with a student from Acholi on 20 July 2014 in Makerere University.
} 
essence of gender equality does not work for rural women who view it as an abomination, unlike folk in the urban setting influenced by other cultures. Yet another informant views women as emotional and volatile, thus argues that they should not be allowed to become soldiers. His argument is that unlike men, women's anger precedes rational judgement therefore it is unwise to give them weapons lest they grossly err." ${ }^{43}$ Such opinions exist in people with masculine culture mind-set where gender role alteration is the concern of the informants.

According to Hofstede there is a global tendency in masculine cultures to associate men with assertiveness, toughness, and women with modesty, tenderness, and concern with quality of life. ${ }^{44}$ Masculine cultures echo a position similar to that of Acholi culture which treats all women as modest, tender and non-violent. Basing on Hofstede's notion, the perception of masculine culture is that women are unfit to be combatants since the fierceness of battles contradicts their natural personalities of modesty and tenderness.

In masculinity cultures all women are assumed or expected to be born with a virtue of gentleness while in femininity cultures gentleness could be a virtue for men also. Masculinity cultures have the tendency to define and generalize women behaviour as gentle and moderate and thus justify it as a reason to prevent them from participating in violent and aggressive acts like war. Acholi is a true example of masculinity cultures, women in Acholi culture were forbidden to fight because of their biological makeup and socio-culturally constructed behaviour. Besides differentiating and predestining behaviour, masculinity cultures also shape the potentiality of the different gender in role performance. A rehabilitation worker noted that, "Now there is a situation where girls are taught to assemble and dismantle guns, they ambush, lay landmines and fight with children on their backs." 45 The society posits that since tradition and culture prevented

\footnotetext{
${ }^{43}$ Interview with a student from Acholi on 16 July 2014 in Makerere University.

${ }^{44}$ Hofstede, 297.

${ }^{45}$ Interview with a rehabilitation worker on 11 February 2008, at World Vision Rehabilitation Centre in Gulu.

${ }^{46}$ Barth, 2.
}

women from going to war by virtue of their biological make up, they do not possess the intelligence and potential to master skills and knowledge in the military field. Little wonder that the rehabilitation centre worker was dazed that the women were armed with skills to dismantle and assemble guns like men.

Switching of gender roles is unfamiliar to the traditional Acholi culture. The cultural conception that war is a male preserve impacts on many parts of Africa and affects female returnees who face many challenges during their reintegration. Elise Barth explains the gender experiences of rebel soldiers in Africa thus:

While men are perceived to have strengthened their gender roles through military knowledge and experiences and are considered more masculine than before, women soldiers are marginalised and are pushed to the direction of traditional gender roles considered more acceptable for women in that particular society. ${ }^{46}$

Meredith Turshen and Clotilde Twagiramariya support Barth's observation when they record that in most African cultures' militarization is considered a man's affair. ${ }^{47}$ Similarly, Tinkasiimiire is of the view that African cultures exempt women from participation in war. ${ }^{48}$ Subsequently, like most African traditions, Acholi culture does not permit women to be involved in war. This cultural perception leaves the female returnee in dilemma during the reintegration: they cannot fully identify themselves with the society's core values, are stigmatized and often feel dejected. They face the challenge of total acceptance not only as killers but rather victims of socio-cultural dimensions. The reality that LRA women fought using guns makes the society doubt their feminine qualities of

\footnotetext{
${ }^{47}$ Meredith Turshen. 'Women's War Stories', in What Women Do in Wartime: Gender and Conflict in Africa. London and New York: Zed Books (1998), 39.

48 Theresa Tinkasiimire. 'Women and War in Northern Uganda: A Theological Reflection on the Dignity of a Woman in the Reintegration Process', in Baard Maeland, (ed), Culture, Religion, and the Reintegration of Female Child Soldiers in Northern Uganda. New York: Peter Lang, (2010), 166-167.
} 
gentility, modesty, tenderness and being vessels for blessings.

It is remarked here that not all people in Acholi are stuck to the traditional dictum that exempts women from participating in military matters. A certain class of mainly elitist women who subscribe to Western outlook argues that in Uganda several women get recruited on voluntary basis, and others even have higher ranks than their male counterparts. They wonder why then the LRA returnees should be condemned for their identities as female combatants! Thus, they do not see the gist of such debates. ${ }^{49}$ It should be observed that the percentage of women in UPDF that the above informant alludes to is so small, less than $10 \% .^{50}$ The second informant from this category said that in the wake of modernity, he did not see any problem that women were soldiers. ${ }^{51}$ It must be stressed that these views are outside the box of Acholi traditional cultural perspective, and greatly contradict the Acholi cultural values and traditional mind-set where gender roles are collectively defined and diversified, and in addition cultural changes are not easily accepted.

The archbishop's remarks that the presence of women soldiers is new and strange in the minds of people who still keep the traditional culture are apt. The people are not tolerant to what is alien to their culture and hesitant to accept what is new and unfamiliar to their culture. It is the new identity and status that these women acquired in the bush as combatants that makes them undergo silent stigma! There is a feeling of them having violated and detached themselves from the Acholi traditional culture! Acholi traditional culture is more of masculinity, high uncertainty avoidance collective culture.

This attitude also explains why some of the girls who learned survival skills in the bush have immense trauma in the reintegration process. ${ }^{52} \mathrm{On}$ return, the community emphasised and reinforced

${ }^{49}$ Interview with a student from Acholi on 16 July 2014 in Makerere University.

${ }^{50}$ This information was obtained from http://rosebellkagumire.com/2010/11/08/women-in-ugandamilitary-no-family-planning-services-no-promotions/

${ }^{51}$ Interview with an informant on 9 February 2008 at Transa Rock Hotel in Gulu. traditional patterns and rituals rather than the new roles that the girls and women had acquired during armed conflict. ${ }^{53}$ The phenomenon could be explained by the rigidity of punctuated gender roles in masculinity cultures to which the Acholi subscribes. Coulter, Persson and Utas note that,

These women want to seek a life of their own and often behave in ways contrary to social expectations. Interestingly, these qualities such as strength, independence, courage, persistence, and ... are often not highly valued female characteristics in many African societies, which often promote women's submission, servility, and willingness to endure and accept their subordinate position. ${ }^{54}$

Acholi highly valued human life and it was believed that anyone involved in terminating life regardless of the reason, negative consequences followed the killer and his family. As a collective culture, the new status of the female combatant is not an individual's concern but the community's. When these women are reintegrated into a collective society which does not believe in women combatants, they find themselves under a lot of cultural pressure since some of the collective ways of thinking from the community alienate them. Their personal lifestyles cease to be private but a communal concern. The section below makes an evaluation of the kwero merok ritual towards women in Acholi society.

\section{Evaluation of Kwero Merok in Reintegrating Female Combatants}

- The articles indicate that kwero merok plays a significant role in welcoming and cleansing the female returnees from evil spirit (cen) that could have possessed them due to the numerous atrocities they committed, including killing. The preceding rituals before kwero merok such as nyono tong gweno and lwoko pig wang act as curtain raisers in welcoming the female returnee combatants. Therefore, kwero merok as a

\footnotetext{
52 McKay, 159.

${ }^{53}$ Ibid, 19.

${ }^{54}$ Chris Coulter et al. Young female fighters in African Wars: Conflict and Its Consequences. Uppsala: Nordiska Afrikainstitutet, (2008), 14.
} 
cleansing ritual assured the female returnee combatants and other members of the community of deliverance from cen.

- This ritual is also a non-verbal but symbolic communication to the returnees that the community still loves and receives them regardless of the horrendous deeds in war time. Baines attests to this prime significance of the ritual, noting that, "Returnees who were solitary prior to the ceremony were now more sociable, they were better able to converse in a 'normal' manner, and aggressive behaviour tended to reduce or disappear." 55

- Traditional rituals did provide the returnees and the community members with the liberating experiences as well as the bonding fibre, since family members were notified prior to the rituals. It also widened the relation horizon since the returnees were introduced to other members of the family and clan.

- In addition, the use of these Acholi rituals in the reintegration of female returnees revived and transmitted the meaning and values of these traditional rituals to the next generation, indeed a lot of research and publications have been done.

\section{Weakness of kwero merok in Reintegrating Female Combatants}

- Acholi traditional culture is a masculine culture in which gender roles for men and women are distinct and fighting was basically a man's role. Thus, war rituals such as kwero merok were meant for men and not women because culturally fighting was a man's role. As earlier stated, kwero merok ritual was used to welcome, congratulate and cleanse the soldiers who had been in the war from cen as they came back into the community. One may question what difference it makes if used with women? In response to this question, while these rituals might welcome them back, cleanse them from possible possession of cen, they however, cannot restore their culturally changed and soiled identity due to the swapping of gender roles while in LRA camps! Their cultural status and identity are collectively questioned by the society because the idea of soldiers in Acholi meant men and never women. Much as Mpyangu states that after the rituals the female returnees were living harmoniously with others in the community and were not being haunted by cen. ${ }^{56}$ the partial peace enjoyed here was possible because people no longer suspected them of being possessed by cen, but not because they were comfortable with their status as female combatants.

Stigma happens later because some of the community members were not only bothered by what these women had done as a result of being soldiers, but also what such a role did to their status and identity as Acholi women. That is why some of the informants indicated their hesitation in accepting LRA female combatants even after they had been cleansed of cen through the kwero merok ritual. For some men and women, the level of aggression that some of these women exhibited is a threat to their masculine culture.

- It is crucial to note that culture has various levels and that people's beliefs and practices are not only determined by rituals but also accompanied with values that have meaning to the people. Unless accompanied with values, rituals have no meaning to practitioners. If people are to change their attitude towards female combatants in masculinity cultures, then rituals performed must be accompanied by the underlining transformative values, related to the acceptance of gender role alteration. Rituals alone unaccompanied with values cannot transform people with certain values. Often gender role alteration in masculinity culture is accompanied with stigma because people's values have not been transformed to accept such a change.

- The alteration of kwero merok rituals performed on these women was not only applied to the wrong people but also for a wrong purpose, since war rituals in Acholi were meant for heroes who had gone to battles and came back triumphant. It was more of the celebration of the victory rather than what the LRA did for killing their own

\footnotetext{
${ }^{55}$ Baines, 45.
}

${ }^{56}$ Mpyangu, 149.

78 This work is licensed under a Creative Commons Attribution 4.0 International License. 
people. One would question: if kwero merok has cleansed cen, why does it not change the perceptions of the people on the identity and status of these women as rebels who tortured and killed Acholi people? The answer is simple: they are viewed as people who have betrayed their status and sense of identity in a collective culture such as Acholi by killing their own people!

It should be taken into account that rituals are a onetime event, but values take time to change and that is why their status and identity as rebels will take time to vanish in the minds of the people even after they have undergone these rituals.

- Reintegration is a long-term process because it involves change in the general concepts of values. The transformation of values is gradual but very important and must go together with rituals as symbolic acts in shaping the beliefs and actions of people towards the identity and status of these women.

\section{CONCLUSION}

The article cautions that the stigma that the female returnees experience even after going through the different rituals is an indication that they are not fully reintegrated! Acholi traditional culture was in this case selected because it has been a pioneer through its traditional rituals to reintegrate these women in the Northern Ugandan community. However, it was noted in this article that cultural rituals such as kwero merok cannot fully reintegrate LRA female combatants.

This new acquired status and identity as female combatants and rebels who killed their own people enormously contradicts the traditional Acholi norms which collectively diversify gender roles for men and women. As noted in the evaluation, although kwero merok played a key role in welcoming, cleansing and bonding these women to their kin, it did not attend to the cultural problem of violating traditional gender roles by involving these women in fighting! It therefore, did not restore their sense of loyalty resulting from torturing their own people while they were in the LRA!

\footnotetext{
${ }^{57}$ The Jerusalem Bible, John 8:3-11
}

The traditional ritual of kwero merok has failed to fully reintegrate these women partly due to the inferior place African cultures in general, and Acholi culture, gives to them! Bishop Odama, himself an Acholi tends to look for the positive roles women played in Acholi culture. While we applaud efforts in its service to the poor and marginalized, there is acute need for the church to make its voice heard loud and clear with regard to the role and position of women. It should emulate Christ who ministered to the down-trodden women who were discriminated against by Jewish culture, e.g., the woman caught in adultery. ${ }^{57} \mathrm{With}$ the use of its Liberation and Inculturation theologies, there is urgent need for the church to remove women from the situation of being marginalized socially, politically, economically and religiously, which they have suffered almost universally, and help usher them into a more equitable and humane world. Perhaps some introspection would be a good point to begin from.

79 | This work is licensed under a Creative Commons Attribution 4.0 International License. 